\title{
Hot Tensile and Creep Rupture Data Extrapolation on 2.25Cr-1Mo Steel Using the CDM Penny-kachanov Methodology
}

\author{
José Francisco dos Reis Sobrinho ${ }^{\mathrm{a}}$ Levi de Oliveira Bueno ${ }^{\mathrm{b} *}$ \\ ${ }^{\mathrm{a}}$ Federal Institute of Education, Science and Technology of Piauí - CEFET/PI, \\ Praça da Liberdade, 1597, CEP 64000-040, Teresina, PI, Brazil \\ ${ }^{\mathrm{b}}$ Department of Materials Engineering, Federal University of São Carlos - UFSCar, \\ Rod. Washington Luiz, km 235, CEP 13565-905, São Carlos, SP, Brazil
}

Received: September 12, 2013; Revised: November 22, 2013

\begin{abstract}
Hot tensile and creep data were obtained for 2.25Cr-1Mo steel, ASTM A387 Gr.22CL2, at the temperatures of 500-550-600-650-700 ${ }^{\circ} \mathrm{C}$. Using the concept of equivalence between hot tensile data and creep data, the results were analyzed according to the methodology based on Kachanov Continuum Damage Mechanics proposed by Penny, which suggests the possibility of using short time creep data obtained in laboratory for extrapolation to long operating times corresponding to tens of thousands hours. The hot tensile data (converted to creep) define in a better way the region where $\beta=0$ and the creep data define the region where $\beta=1$, according to the methodology. Extrapolation to $10,000 \mathrm{~h}$ and $100,000 \mathrm{~h}$ is performed and the results compared with results obtained by other extrapolation procedures such as the Larson-Miller and Manson-Haferd methodologies. Extrapolation from ASTM and NIMS Datasheets for $10,000 \mathrm{~h}$ and $100,000 \mathrm{~h}$ as well as data from other authors on $2.25 \mathrm{Cr}-1 \mathrm{Mo}$ steel are used for assessing the reliability of the results.
\end{abstract}

Keywords: $2.25 \mathrm{Cr}$-1Mo steel, hot tensile data, creep data, CDM Penny methodology, data extrapolation

\section{Introduction}

A simplified extrapolation procedure from shorter creep rupture data to longer times was proposed by Penny ${ }^{1}$ based on Continuum Damage Mechanics (CDM) concepts originally developed by Kachanov ${ }^{2}$. According to this method, the time to failure, $t_{f}$ is given by:

$t_{f}=t_{r}-\bar{t}$

where

$t_{r}=\frac{1}{B k \sigma^{k}}$

and

$\bar{t}=\frac{1}{B k \bar{\sigma}^{k}}$

$B$ and $k$ are material constants obtained from curve fitting, $\sigma$ is the applied creep stress (in fact $\sigma=\sigma_{0}$, the initial stress in a constant load creep test) and $\bar{\sigma}$ is the flow stress. The value of $\bar{\sigma}$ has a lower limit equal to the Yield Strength and an upper limit equal do the Ultimate Tensile Strength, and can be set equal to the stress level of a short-time creep rupture test for calculation and graphing purposes, as recommended by Penny ${ }^{1,3}$.

Figure 1 illustrates the stress-strain-time relationships for tensile deformation in general, involving tensile testing, creep testing and stress relaxation testing ${ }^{3}$.

*e-mail: levi@ufscar.br
Figure 2 shows schematically how the parameters $t$, $t_{r}, \beta$ and $\mathrm{k}$ are defined on the modified Kachanov brittle rupture curve ${ }^{3}$.

It is interesting to notice that Equation $2 \mathrm{~b}$ produces the following relation between $\bar{\sigma}$ and $\bar{t}$ :

$\log (\bar{\sigma})=(1 / k) \cdot \log (1 / B k)-(1 / k)(\log (\bar{t})$

Therefore, the value $A=-\log (B K) / k$ corresponds to the intercept of the brittleness line $\beta=1$ with the $\log (\sigma)$ axis, and $(-1 / k)$ corresponds to its slope.

The time to creep failure is given by: $t_{f}=\beta t_{r}$, so that $\log t_{f}=\log \beta+\log t_{r}$, and the characterization of the $\beta$ factor is of also of great importance.

The values of $\bar{\sigma}, k, B$ and $\bar{t}$ can be determined by curve fitting using the experimental data of $\log \sigma$ versus $\log t_{\rho}$ i.e. using the relation:

$\log \left(t_{f}\right)=\log \left(\frac{1}{B k \sigma^{k}}-\bar{t}\right)$

The sensitivity of the method to the procedure of curve fitting, which includes a manually chosen value of $k$, has been discussed by Penny ${ }^{1}$. The performance of the method using curve fitting procedure has also been discussed and several examples of extrapolation presented in literature ${ }^{1,4,5}$. Le May ${ }^{6}$ has recently reviewed the principles of this methodology from the standpoint of remaining life prediction. 


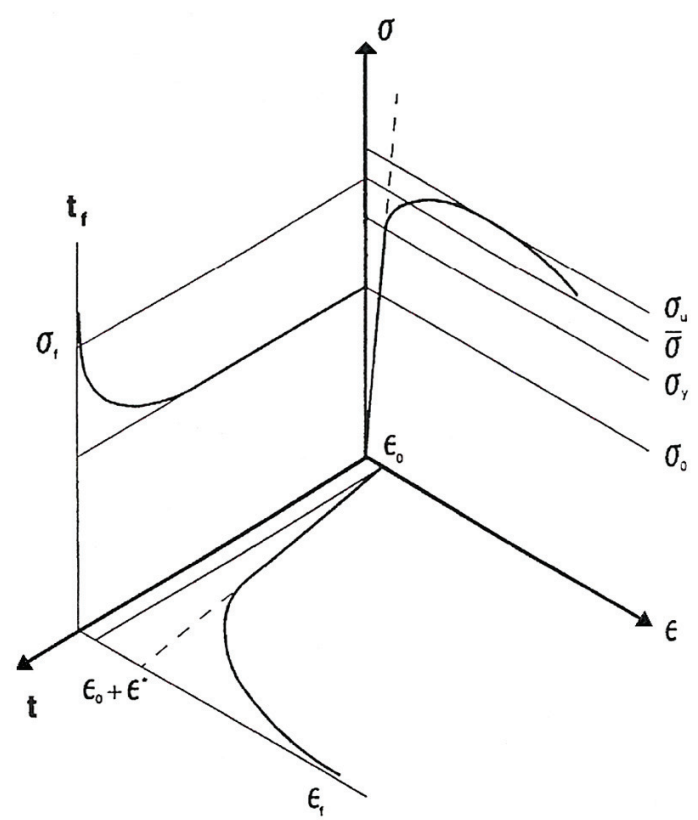

Figure 1. Schematic stress-strain-time relationships in tension ${ }^{3}$.

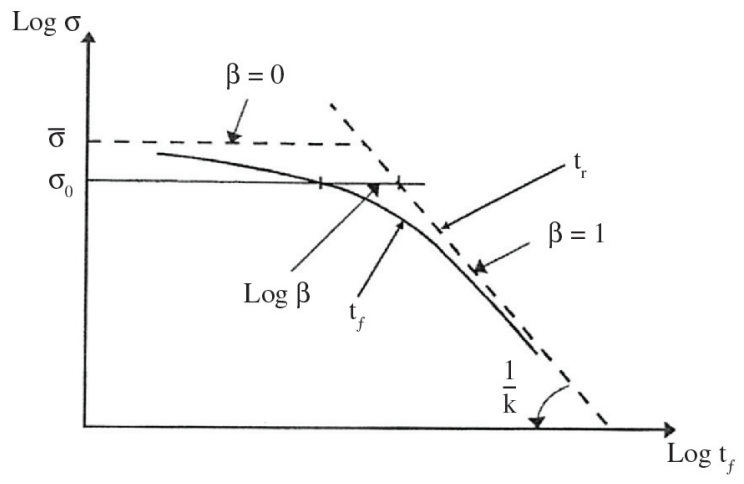

Figure 2. The modified Kachanov brittle rupture curve ${ }^{3}$.

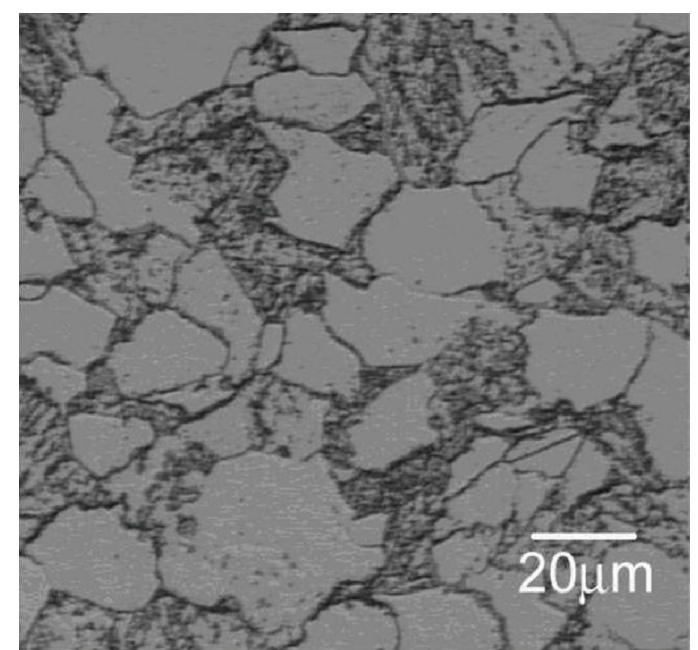

(a)
In the present work, the characterization of the $\bar{\sigma}$ parameter was performed with better accuracy, since, instead of using "short time creep tests", a set of hot tensile tests were carried out at different temperatures and crosshead speeds, with their results combined with the creep results in the analysis, as will be described in the next session.

\section{Material and Methods}

The steel was supplied in plate form with $25.4 \mathrm{~mm}$ thickness, according to ASTM A 387, grade 22 class 2, in the normalized and tempered condition, with the following chemical composition: $\mathrm{Fe}-2.09 \mathrm{Cr}-1.08 \mathrm{Mo}-0.097 \mathrm{C}$ $-0.32 \mathrm{Si}-0.50 \mathrm{Mn}-0.007 \mathrm{P}-0.002 \mathrm{~S}-0.03 \mathrm{Ni}-0.01 \mathrm{Cu}-$ $0.05 \mathrm{Al}$. Metallographic analysis indicated the presence of about $30 \%$ bainite and $70 \%$ ferrite, as shown in Figures $3 a$ and $3 \mathrm{~b}$.

The specimens for the hot tensile tests and creep tests were extracted from the rolling direction. A gauge length Lo $=25 \mathrm{~mm}$ and an initial diameter $\mathrm{do}=6.25 \mathrm{~mm}$ were used for all specimens.

The hot tensile tests were carried out in a servo-hydraulic 8802 model INSTRON machine, at $500{ }^{\circ} \mathrm{C}, 550{ }^{\circ} \mathrm{C}, 600^{\circ} \mathrm{C}$, $650{ }^{\circ} \mathrm{C}$ and $700{ }^{\circ} \mathrm{C}$, using the following constant crosshead speeds: $0,01-0,25-1,0-5,0$ and $20 \mathrm{~mm} / \mathrm{min}$. In this way, 25 hot tensile tests were performed with a total variation of 3 orders of magnitude in strain rate, i.e. in the range from $6.7 \times 10^{-6}$ to $1.3 \times 10^{-2} \mathrm{~s}^{-1}$. The hot tensile tests were carried out according to ASTM E2 $1^{7}$, however, employing different values of crosshead speeds and not a single value (equivalent to a fixed strain rate), as recommended by the standard.

The creep tests were carried out at constant load, according to ASTM E $139^{8}$, using a set of 10 creep machines model STM-MF 1000. Information about this equipment and testing techniques appeared in a previous publication ${ }^{9,10}$. The elongation of the specimens was followed with creep extensometers having LVDT transducers. The readings from the transducers were collected by a Data Logger, using a scan rate of 6 readings $/ \mathrm{h}$. The creep tests were carried out

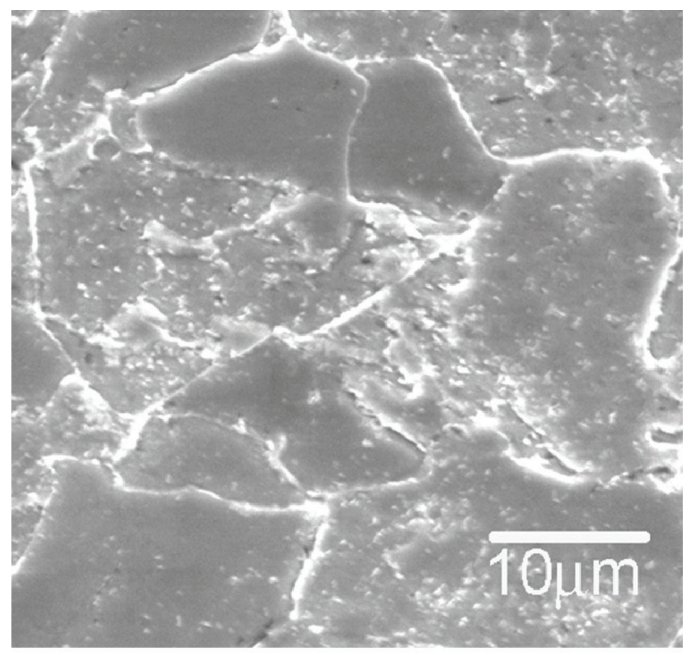

(b)

Figure 3. Microstructure of $2.25 \mathrm{Cr} 1 \mathrm{Mo}$ steel in the as received condition: a) Optical micrograph (500 x, with Nital $2 \%$ ); b) SEM micrograph $(2000 \mathrm{x})$. 
in 9 temperatures levels, namely: $500{ }^{\circ} \mathrm{C}, 525^{\circ} \mathrm{C}, 550{ }^{\circ} \mathrm{C}$, $575^{\circ} \mathrm{C}, 600{ }^{\circ} \mathrm{C}, 625^{\circ} \mathrm{C}, 650{ }^{\circ} \mathrm{C}, 675^{\circ} \mathrm{C}$ and $700{ }^{\circ} \mathrm{C}$, with 17 levels of applied stress, varying from $34.5 \mathrm{MPa}$ to $414 \mathrm{MPa}$, so that 51 creep tests were produced with rupture times varying from 2 to about 1300 hours.

\section{Results and Discussion}

Figure 4 shows the hot tensile data plotted together with the creep rupture data, using a criterion of equivalence proposed to correlate results from both kind of tests ${ }^{11,12}$. According to this criterion: the UTS, the nominal strain rate and the time to reach UTS in a hot tensile test corresponds respectivelly to the applied stress, the minimum creep rate and the rupture time in a creep test.
The verification of validity of this methodology for various materials has been demonstrated in various publication $^{13-17}$.

Figure $5 \mathrm{a}$ and $5 \mathrm{~b}$ show the data presented in Figure 4 subjected to parameterization analysis, according to two different procedures: the Larson-Miller and the MansonHaferd methodologies, respectively ${ }^{16}$. Although the LarsonMiller analysis is more popular and widely applied for extrapolation in several situations, with the present data the best results were obtained with the analysis of MansonHaferd, as evident from comparison between Figures 5a and $5 b^{17}$.

Figure 6 a shows the hot tensile plotted together with creep data at $500^{\circ} \mathrm{C}$ on the diagram $\log (\sigma) \times \log \left(\mathbf{t}_{\text {rupt }}\right)$, with

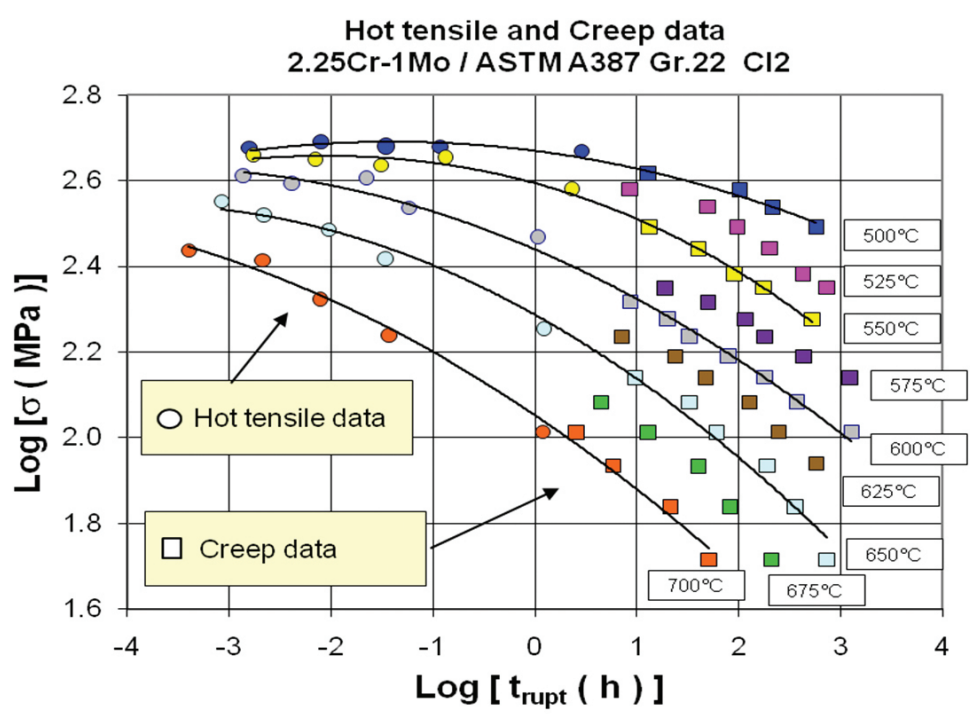

Figure 4. Hot tensile data plotted with creep data, according to the equivalence criterion proposed for analysing both kind of results together. Loss of creep strength with the rupture time.

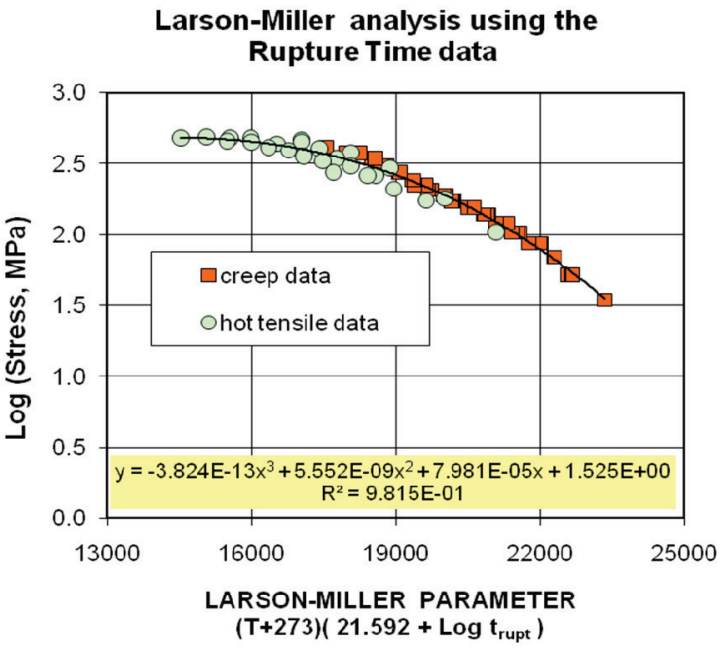

(a)

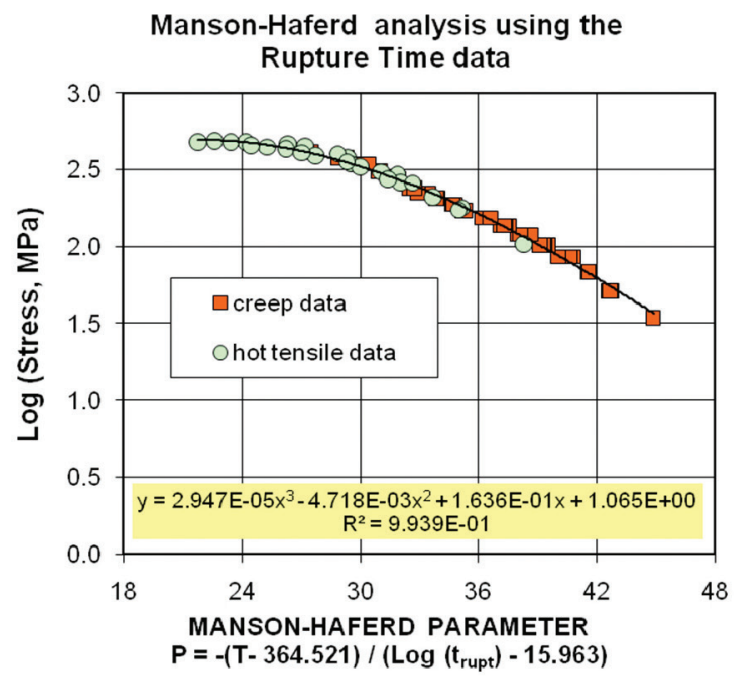

(b)

Figure 5. Hot tensile data plotted with creep data, according to the equivalence criterion proposed for analysing both kind of results together: a) result by the Larson-Miller analysis; b) result by the Manson-Haferd method. 


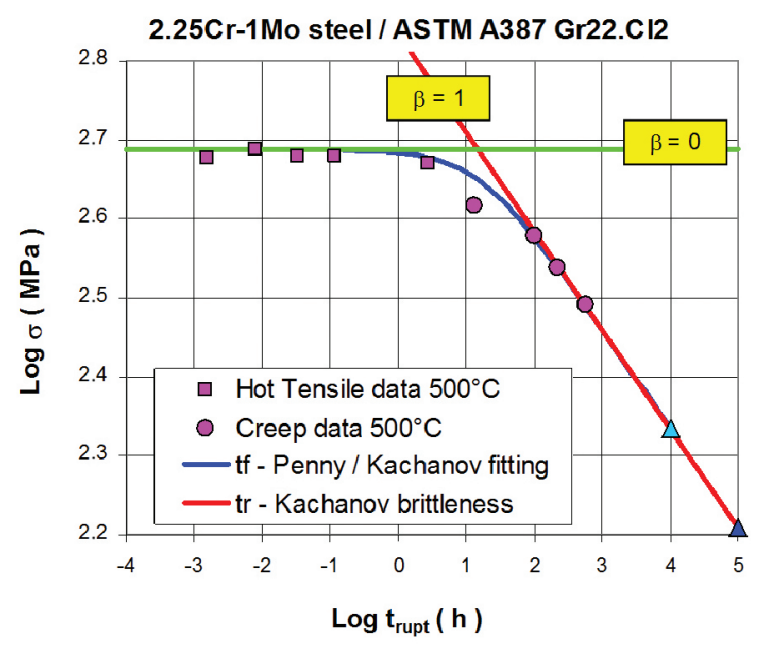

(a)

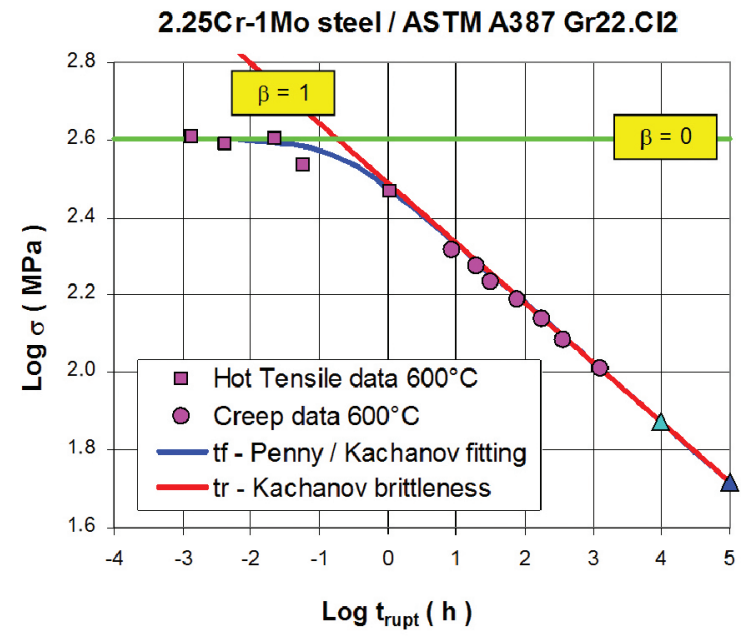

(c)

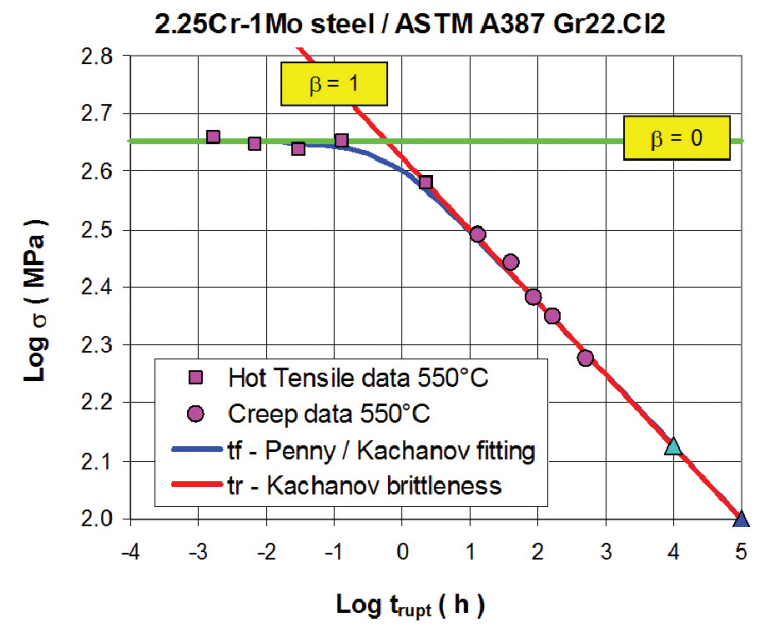

(b)

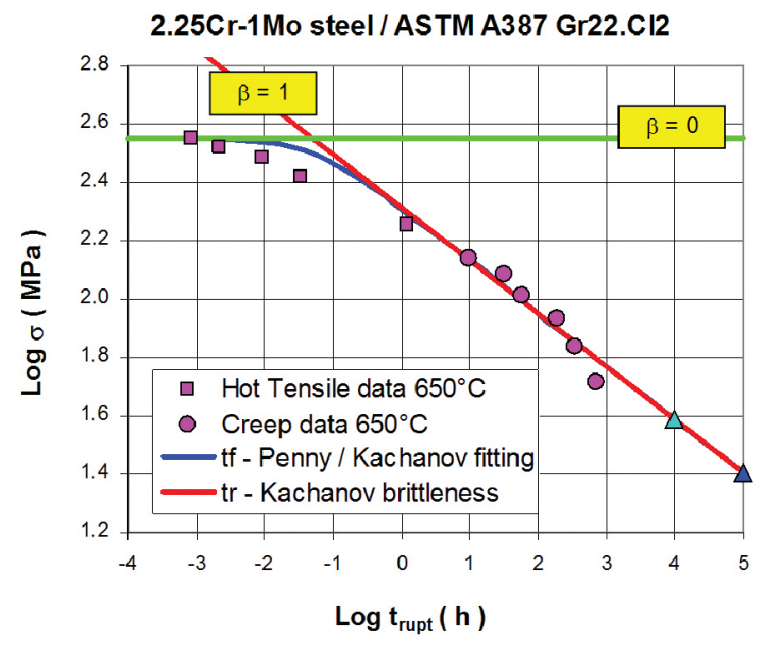

(d)

\subsection{Cr-1 Mo steel / ASTM A387 Gr22.Cl2}

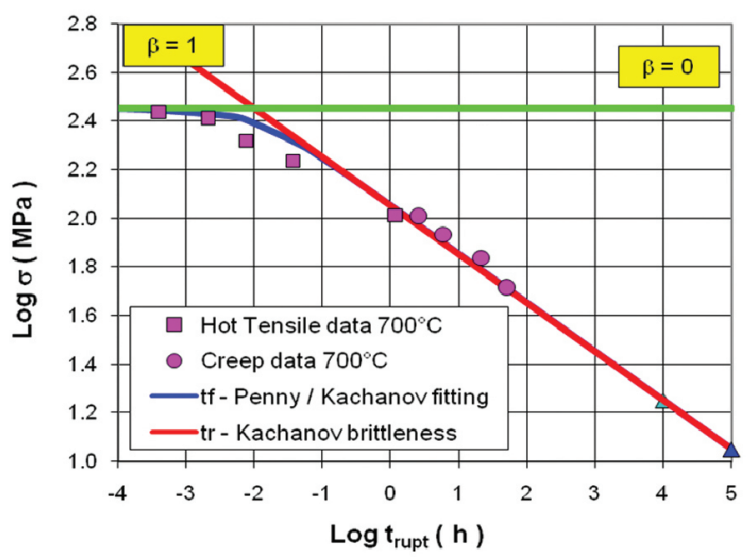

(e)

Figure 6. Hot tensile and creep data on $2.25 \mathrm{Cr}-1 \mathrm{Mo}$ steel analysed by the Penny procedure ${ }^{1}$, at temperatures of : a) $500{ }^{\circ} \mathrm{C}$; b) $550{ }^{\circ} \mathrm{C}$; c) $600{ }^{\circ} \mathrm{C}$; d) $650{ }^{\circ} \mathrm{C}$; e) $700{ }^{\circ} \mathrm{C}$. 
the curve $\mathbf{t}_{f}$ (in blue), determined by the Penny-Kachanov ${ }^{1,2}$ fitting, and the straight line corresponding to $\mathbf{t}_{r}$ Kachanovbrittleness obtained by extrapolation (in red). The horizontal line (in green) represents the condition where $\beta=0$. The rupture strengths predicted for 10,000 and $100,000 \mathrm{~h}$ are also indicated. The parameter $\mathbf{t}_{\text {rupt }}$ used to plot the experimental data corresponds here to the parameter $\mathbf{t}_{f}$ adopted by Penny ${ }^{1}$ in his methodology.

Using a standard procedure of curve fitting, considering Equation 4, the following constants were determined: $k=8, \bar{\sigma}=486.41 \mathrm{MPa}, \bar{t}=15.000 \mathrm{~h}, \mathrm{Bk}=2.128 \times 10^{-23}$ and $\mathrm{A}=2.834$ (the intercept of the brittleness line $(\beta=1)$ with the $\mathrm{Y}$-axis, for $\log \left(\mathbf{t}_{\text {rupt }}\right)=0$ ). The stress levels for attaining $10,000 \mathrm{~h}$ and $100,000 \mathrm{~h}$ are, respectively, 215.7 MPa and 161.8 MPa, which are shown by the triangles (in light blue e dark blue, respectively) in Figure 5a. Several values of $k$ were tried in the analysis, but finally it was chosen the value of $k=8$, which was verified to minimize the sum of the squared error between the predicted and the observed ruptures times.

Figure $6 \mathrm{~b}$ refers to the data obtained at $550{ }^{\circ} \mathrm{C}$. In this case, the same procedure of analysis was applied, i.e. the value of $k$ was best taken as $k=8$, and the following parameters determined: $\bar{\sigma}=449.50 \mathrm{MPa}, \bar{t}=0.600 \mathrm{~h}$, $\mathrm{Bk}=1.00 \times 10^{-21}$ and $\mathrm{A}=2.625$. The stress levels for attaining $10,000 \mathrm{~h}$ and $100,000 \mathrm{~h}$ are, respectively, $133.4 \mathrm{MPa}$ and 100.0 $\mathrm{MPa}$ at $550{ }^{\circ} \mathrm{C}$.

Figure $6 \mathrm{c}$ refers to the data obtained at $600{ }^{\circ} \mathrm{C}$. In this case, the value of $\mathrm{k}$ was best taken as $k=6.5$ and the parameters were: $\bar{\sigma}=401.05 \mathrm{MPa}, \bar{t}=0.180 \mathrm{~h} \mathrm{e}$ $\mathrm{Bk}=6.667 \times 10^{-17}$ and $\mathrm{A}=2.489$. The stress levels for attaining $10,000 \mathrm{~h}$ and $100,000 \mathrm{~h}$ are, respectively, $74.7 \mathrm{MPa}$ and $52.4 \mathrm{MPa}$ at $600{ }^{\circ} \mathrm{C}$.

In the analysis of the data at $650{ }^{\circ} \mathrm{C}$ (Figure 6d) and $700{ }^{\circ} \mathrm{C}$ (Figure 6e) the value of $k$ was best taken as $k=5.5$ and $k=5.0$, respectively, with the following set of parameters determined: $\bar{\sigma}=375.26 \mathrm{MPa}, \bar{t}=0.05 \mathrm{~h}, \mathrm{Bk}=1.818 \times 10^{-13}$ and $\mathrm{A}=2.316$ for $650{ }^{\circ} \mathrm{C}$ and $\bar{\sigma}=282.52 \mathrm{MPa}, \bar{t}=0.01 \mathrm{~h}$, $\mathrm{Bk}=5.556 \times 10^{-11}$ and $\mathrm{A}=2.051$ for $700^{\circ} \mathrm{C}$. The stress levels for 10,000 and 100,000 $\mathrm{h}$ are respectively: $38.8 \mathrm{MPa}$ and 25.6 MPa at $650{ }^{\circ} \mathrm{C}$, and $17.8 \mathrm{MPa}$ and $11.2 \mathrm{MPa}$ at $700^{\circ} \mathrm{C}$.

Table 1 gives the complete set of values for the parameters $k, \mathbf{B}, \bar{\sigma}$ and $\bar{t}$ and Figures $7 \mathrm{a}, 7 \mathrm{~b}, 7 \mathrm{c}$ and $7 \mathrm{~d}$ show, respectively, their variation with temperature.

Figure $7 \mathrm{a}$ and $7 \mathrm{~b}$ indicate that the values of $k$ and $\mathbf{B}$ decrease and increase linearly, respectively, with the increase in temperature and the legends in the figures present the regression coefficients determined for the data. According to Equation 2a and Figure 2, the value $-1 / \mathrm{k}$ correspond to the slope of the Kachanov ${ }^{2}$ brittleness line, and it is easy to verify that the slopes of the curves in Figures 6a to 6e decrease as temperature increases, and therefore $\mathrm{k}$ decreases.

Figure $7 \mathrm{c}$ and $7 \mathrm{~d}$ indicate that the parameters $\bar{\sigma}$ and $\bar{t}$ also decrease linearly with temperature. The values of $\bar{\sigma}$ are connected to the ultimate tensile stress of the material, and their reduction with temperature is a predictable behavior. The value of $\bar{t}$ corresponds to the intersection of the line $t$ with the line of ultimate tensile stress $\bar{\sigma}$. The decrease of $\frac{r}{t}$ with temperature is also a predictable behavior, since rupture times always decrease with increase in temperature at certain level of stress. The decrease of $\bar{t}$ with temperature is easily verified in Figures 6 a to $6 \mathrm{e}$.

It is important to emphazise the inclusion of the hot tensile data in the present analysis. These kind of data, expressed as creep data (using the criterion of equivalence mentioned previously ${ }^{11}$ ), proves to be very useful for defining the left side of the curve $\log (\sigma)$ vs. $\left(\log \mathbf{t}_{f}\right)$, in Figure 2, or of the curves $\log (\sigma)$ vs. $\left(\log \mathbf{t}_{\text {rupt }}\right)$ in Figures 6 a to 6 e. Thereby, the value of $\bar{\sigma}$ is better identified in the analysis. The values of $\bar{t}$ are also better characterized. A careful observation of Figures $6 \mathrm{a}$ to $6 \mathrm{e}$, shows the evident decrease of $\bar{\sigma}$ nd $\bar{t}$, as test temperature increases.

Figure 8a shows the variation of Creep Rupture Strength for $10,000 \mathrm{~h}$ and for $100,000 \mathrm{~h}$ for the $2.25 \mathrm{Cr}-1 \mathrm{Mo}$ steel under investigation, according to the analysis by the method of Penny-Kachanov ${ }^{1,2}$. The present set of data (with 25 hot tensile results +51 creep test results) were also analyzed by various traditional parameterization methodologies ${ }^{17}$, like: Larson-Miller, Orr-Sherby-Dorn, Goldhoff-Sherby, Manson-Haferd and Manson-Succop. The results according to the methods of Larson-Miller and Manson-Haferd were presented in Figures 5a and 5b. With these two reference curves it was also possible to obtain data of $\sigma_{10,000 \mathrm{~h}}$ and $\sigma$ $100,000 \mathrm{~h}$. Data of these allowable stresses could also be obtained for $2.25 \mathrm{Cr}-1 \mathrm{Mo}$ steel in the normalized and tempered condition from the work of Viswanathan ${ }^{18}$ and from the ASTM Special Report DS $6 \mathrm{~S}^{19}{ }^{19}$, that employed in both cases the Larson-Miller method in their analysis. It was also considered information of the NIMS Datasheets for a similar version of 2.25Cr-1Mo steel for comparison ${ }^{20,21}$. In this case, according to their publication ${ }^{20,21}$, the data were rationalized by the Manson-Haferd method.

Figure 8b presents a comparison of the Creep Rupture Strength for $10,000 \mathrm{~h}$ of the steel according to the PennyKachanov $^{1}$ analysis with results of the same kind reported by the authors mentioned above. It can be observed that the Penny-Kachanov ${ }^{1,2}$ curve is situated in between the Viswanathan's curve ${ }^{18}$, indicating higher creep rupture strength, and the ASTM curve ${ }^{19}$, with lower creep rupture strength.

Table 1. Variation of the parameters $k, \mathrm{~B}, \bar{\sigma}, \bar{t}, \sigma_{10,000 \mathrm{~h}}$ and $\sigma_{100,000 \mathrm{~h}}$ with temperature, according to the Penny-Kachanov $\mathrm{V}^{1,2}$ analysis.

\begin{tabular}{ccccccc}
\hline $\mathbf{T}\left({ }^{\circ} \mathbf{C}\right)$ & $\boldsymbol{k}$ & $\mathbf{B}$ & $\bar{\sigma}(\mathbf{M P a})$ & $\overline{\boldsymbol{t}}(\mathbf{h})$ & $\sigma_{\mathbf{1 0 , 0 0 0 h}}$ & $\sigma_{\mathbf{1 0 0 , 0 0 h}}$ \\
\hline 500 & 8.0 & $2.660 \mathrm{E}-24$ & 486.41 & 15.000 & 215.7 & 161.8 \\
550 & 8.0 & $1.250 \mathrm{E}-22$ & 449.50 & 0.600 & 133.4 & 100.0 \\
600 & 6.5 & $1.026 \mathrm{E}-17$ & 401.05 & 0.180 & 74.7 & 52.4 \\
650 & 5.5 & $3.306 \mathrm{E}-14$ & 357.26 & 0.050 & 38.8 & 25.6 \\
700 & 5.0 & $1.111 \mathrm{E}-11$ & 282.52 & 0.010 & 17.8 & 11.2 \\
\hline
\end{tabular}




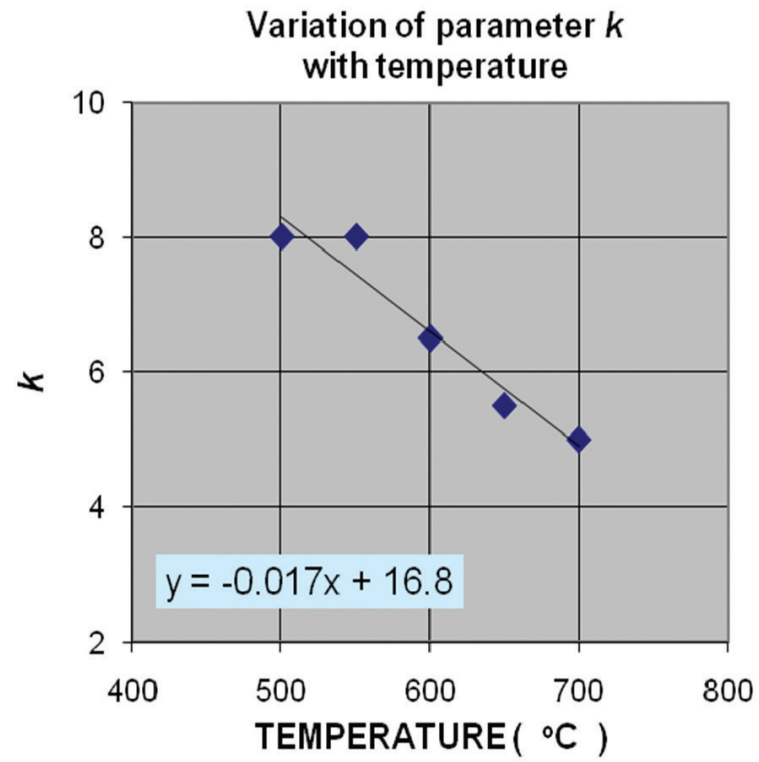

(a)

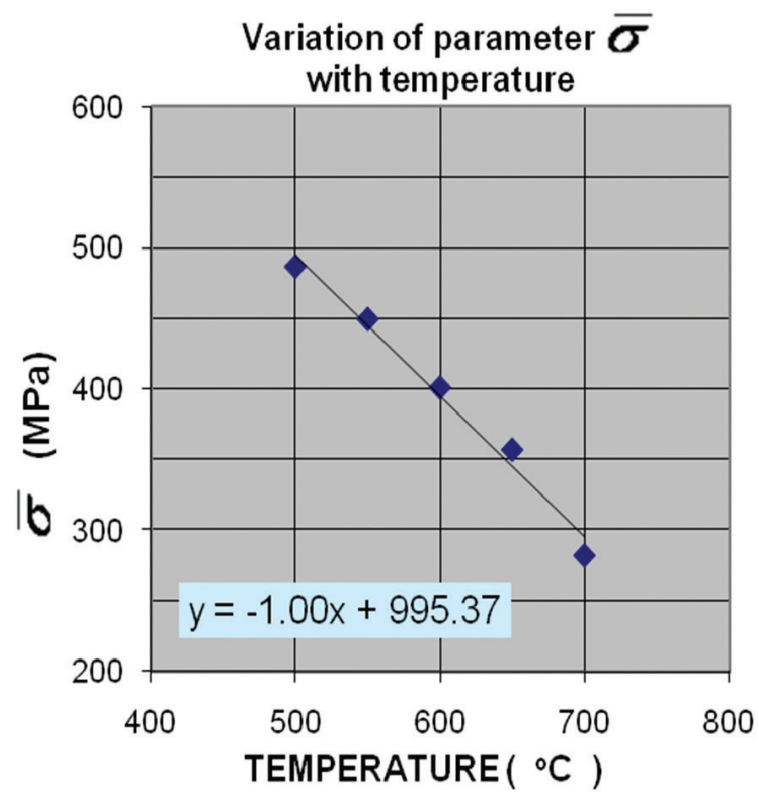

(c)

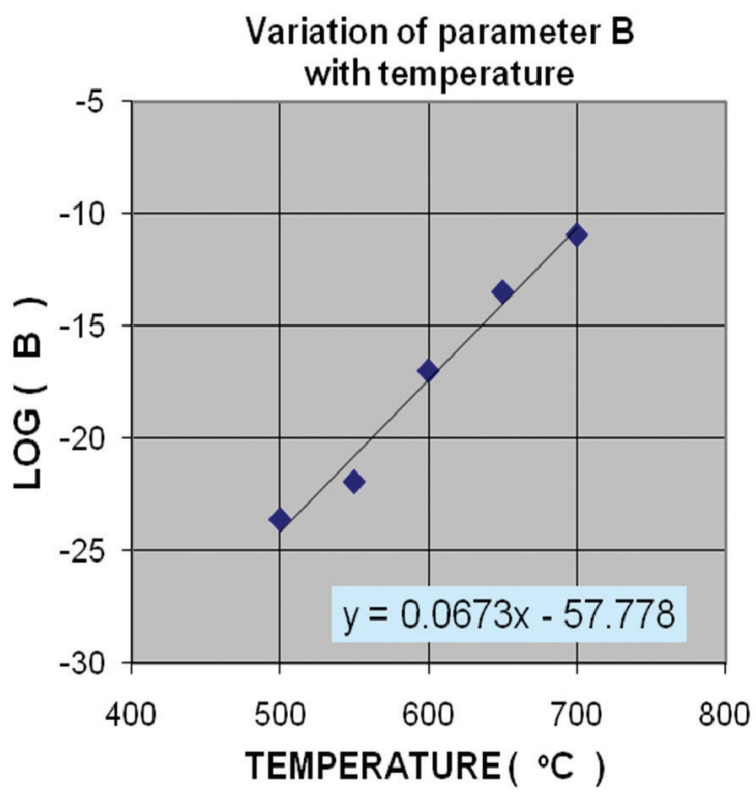

(b)

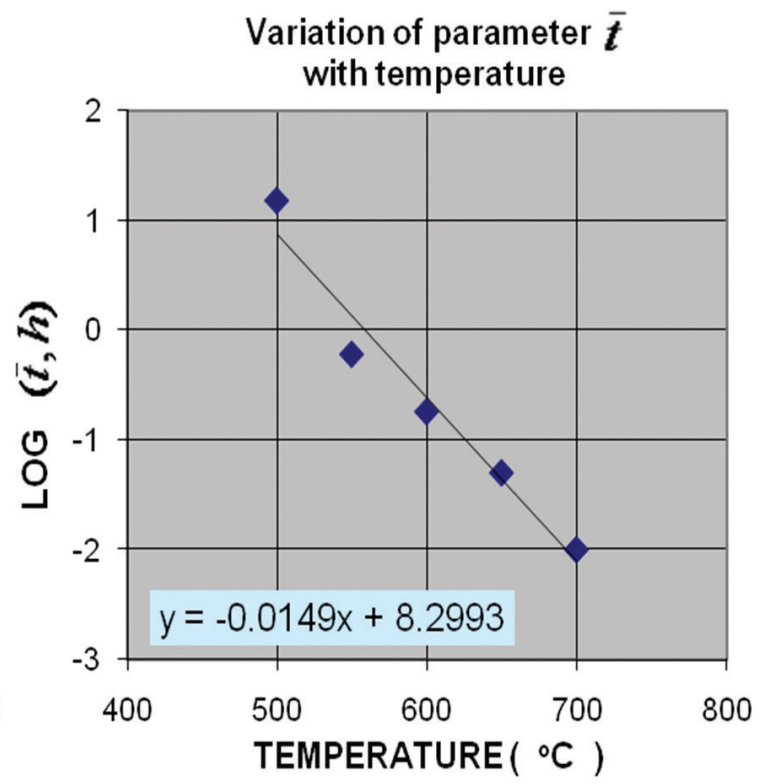

(d)

Figure 7. Variation with temperature of the parameters: a) $k$; b) $\mathbf{B}$; c) $\bar{\sigma}$; d) $\bar{t}$.

The predictions made according to the Larson-Miller and Manson-Haferd methods are situated a little bellow the Penny-Kachanov ${ }^{1,2}$ curve.

In Figure 8c, the comparison refers to the Creep Rupture Strength for $100,000 \mathrm{~h}$ and approximately the same situation is verified: the Penny-Kachanov ${ }^{1,2}$ prediction is located again in between the four other curves.

Figures $8 \mathrm{~d}$ and $8 \mathrm{e}$ indicate that the NIMS data show reasonable agreement with the ASTM data, for $10,000 \mathrm{~h}$ and $100,000 \mathrm{~h}$ respectively. In both situations, the PennyKachanov $^{1,2}$ results are above these predictions.
It is important to point out that the creep rupture strength of the $2.25 \mathrm{Cr}-1 \mathrm{Mo}$ steel is highly dependent on the heattreatment conditions employed in the manufacturing of the material. Figure 9 shows data reported by Viswanathan ${ }^{18}$ presenting Larson-Miller reference curves for this steel under four different heat-treatment states, with remarkable difference between them. Therefore, in the comparison illustrated in Figures $8 \mathrm{~b}$ and $8 \mathrm{c}$, involving the normalized and tempered version of the steel from various sources, and subjected to different procedures of analysis, it seems acceptable that the five curves present the observed differences between each other. 


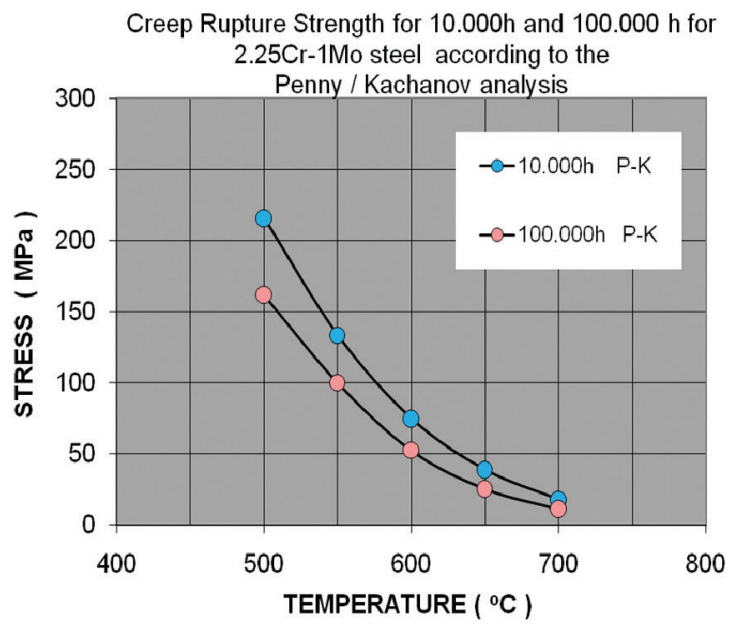

(a)

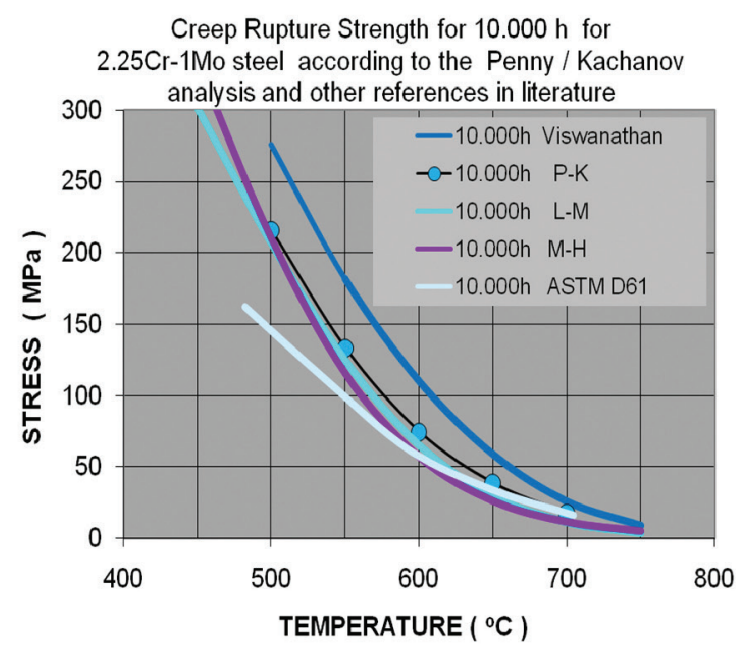

(b)

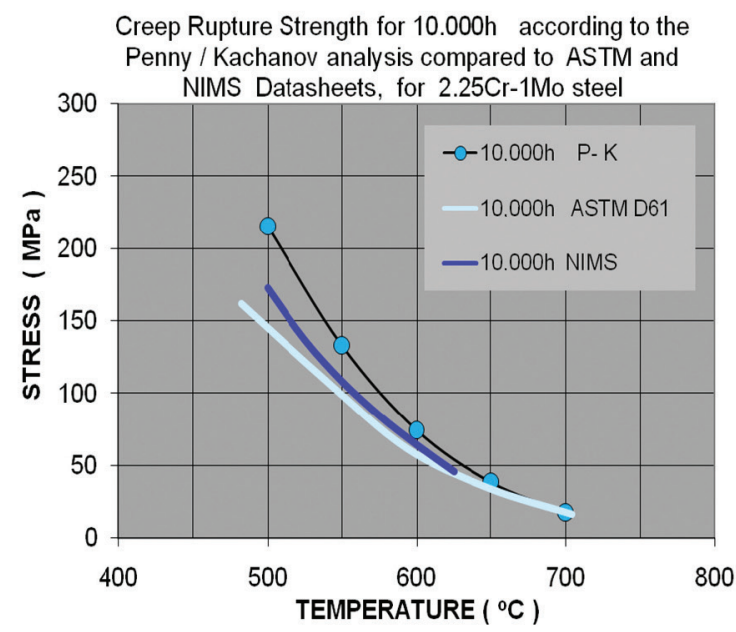

(d)
Creep Rupture Strength for $100.000 \mathrm{~h}$ for 2.25Cr-1Mo steel according to the Penny / Kachanov analysis and other references in literature

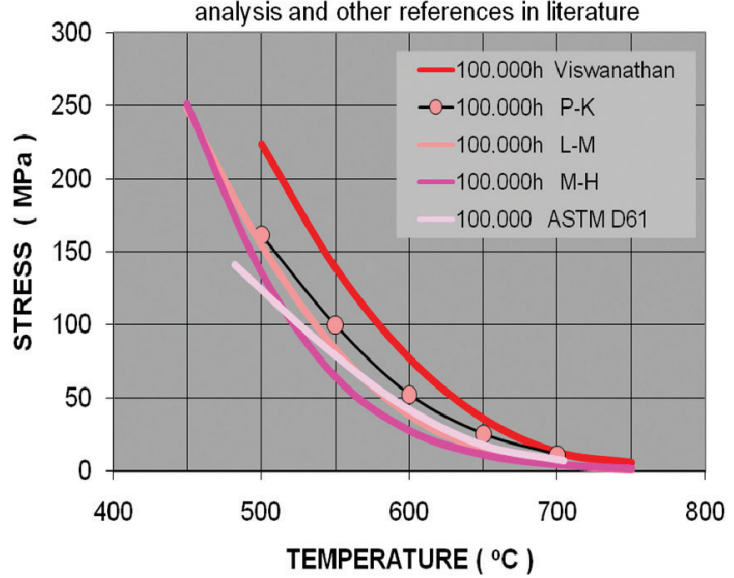

(c)

Creep Rupture Strength for $100.000 \mathrm{~h}$ according to the Penny / Kachanov analysis compared to ASTM and NIMS Datasheets, for 2.25Cr-1Mo steel

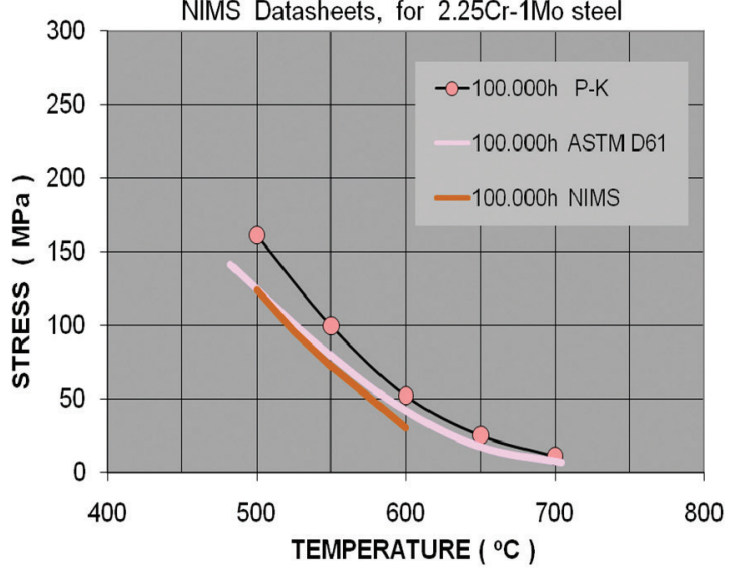

(e)

Figure 8. a) Creep rupture strength for $10,000 \mathrm{~h}$ and $100,000 \mathrm{~h}$ estimated by the Penny-Kachanov method ${ }^{1,2}$; b) Creep rupture strength for $10,000 \mathrm{~h}$ and c) Creep rupture strength for $100,000 \mathrm{~h}$, compared with data from: Viswanathan ${ }^{18}$, ASTM D6 $1^{19}$, Larson-Miller and Manson-Haferd extrapolations ${ }^{17}$; d) Creep rupture strength for 10,000h and e) Creep rupture strength for 100,000 h, compared with data from: ASTM D6 ${ }^{19}$ and NIMS ${ }^{20,21}$ Datasheets. 


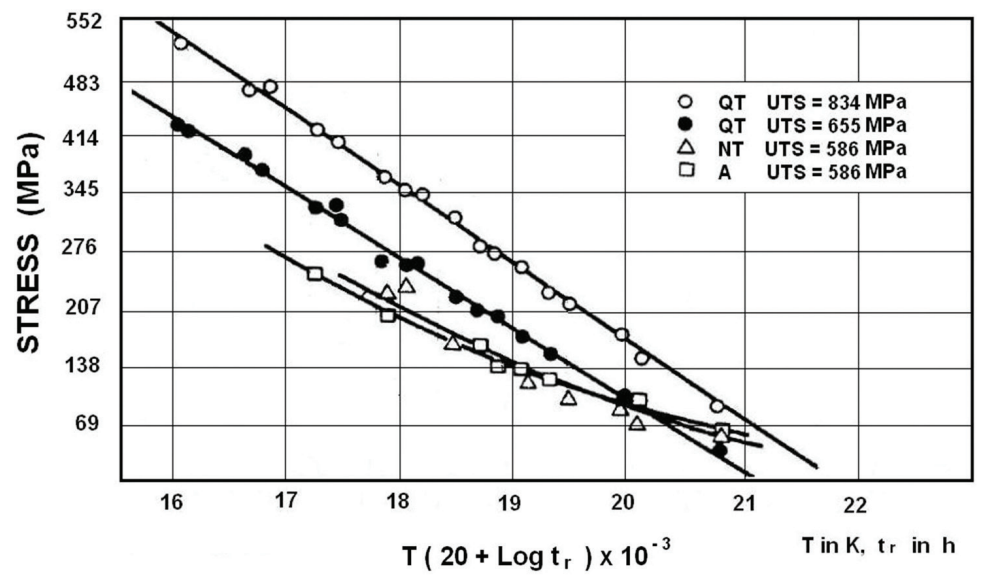

Figure 9. Variation in Creep Rupture Strength of 2.25Cr-1Mo steel under different heat-treatment conditions, plotted using the LarsonMiller parameter. $\mathrm{Q}=$ quenched and tempered; NT = normalized and tempered; A = annealed; UTS = ultimate tensile stress. Obsv. Adapted from R.Viswanatan ${ }^{17}$.

\section{Conclusions}

- The methodology proposed by Penny ${ }^{1}$, based on Kachanov work ${ }^{2}$ was used to analyze a set of high temperature data from hot tensile and short duration creep tests, and it has been observed that the hot tensile data presents the great advantage or revealing better the region where $\beta=0$, and the creep data the region where $\beta=1$, according to the model;

- In the temperature range investigated, i.e. from $500{ }^{\circ} \mathrm{C}$ to $700{ }^{\circ} \mathrm{C}$, the parameters $k, \bar{\sigma}$ and $\operatorname{LOG}(\bar{t})$ where observed to decrease linearly with increase in temperature. On the other hand the parameter LOG(B) was observed to decrease linearly with increase in temperature;

- The Creep Rupture Strength of 10,000h and $100,000 \mathrm{~h}$ were obtained by extrapolation from the Penny-Kachanov ${ }^{1,2}$ methodology and the results are satisfactorily compatible with similar data from other sources in literature;

\section{References}

1. Penny RK. Practical Methods for Creep Assessments: Data Extrapolation and Crack Propagation. In Proceedings of Failures; 2002. EMAS; 2002. p. 119-135.

2. Kachanov LM. Rupture time under creep conditions. International Journal of Fracture. 1958; 97(1-4):11-18. Izvestia Akademii Nauk SSST, Otdelenie Teknicheskich Nauk, n. 8, p. 26-31, 1958. 10.1023/A:1018671022008

3. Penny RK and Mariott DL. Design for Creep. 2nd ed. London: Chapman \& Hall; 1995. http://dx.doi.org/10.1007/978-94011-0561-3

4. Furtado HC, Le May I, De Almeida LH and Peace R. Extrapolation of shorter time creep rupture data using the Damage Mechanics approach of Penny. In: Proceedings of ASME/ JSME Pressure Vessels and Piping Conference - Elevated Temperature Design and Analysis of Plastic Components; 2004. ASME; 2004. p. 11-17. ASME/PVP, n. 472.
- The results obtained with Penny-Kachanov ${ }^{1,2}$ methodology in this work are satisfactorily consistent and the methodology seems viable to be employed with great advantage to generate data for long term operating times, from extrapolation of results of short duration produced in laboratory;

- Validation of the methodology should be tested extensively with data as done in this work (i.e. considering hot tensile and creep testing results) from different metals and alloys.

\section{Acknowledgements}

The authors acknowledge STM-Systems for Testing of Materials Ltd. in São Carlos-SP, Brazil, for the preparation and testing of creep specimens, Mr. Flavio A. S. Serra from REPLAN/Petrobras for supplying the material, and CNPq / CAPES for a grant to J. F. Reis Sobrinho during his D.Sc. postgraduate program at PPG/ CEM DEMa/UFSCar.

5. Furtado HC, Le May I and Peace R. The application of Damage Mechanics concepts to creep data extrapolation and power plant life assessment. In: Proceedings of ECCC Creep Conference; 2005; London. London; 2005. p. 582-591.

6. Le May I. Predicting Remaining Creep Life using Damage Mechanics Principles. Procedia Engineering. 2013; 55:612515. http://dx.doi.org/10.1016/j.proeng.2013.03.303

7. American Society for Testing and Materials - ASTM. ASTM E 21-09. In: Annual Book of ASTM Standards. Philadelphia: ASTM; 2009. v. 03.01, p.1-8.

8. American Society for Testing and Materials - ASTM. ASTM E 139-11. In: Annual Book of ASTM Standards. Philadelphia: ASTM; 2011. v. 03.01, p. 309-319.

9. Bueno LO. Máquinas-protótipos para ensaios de fluência em metais a altas temperaturas. Parte 1: Detalhes de construção e montagem do equipamento. In: Anais do II Encontro de Tecnologia e Utilização dos Aços Nacionais; 1987; Rio de Janeiro. Rio de Janeiro; 1987. p. 916-934. 
10. Bueno LO and Pigatin WL. Máquinas-protótipos para ensaios de fluência em metais a altas temperaturas. Parte 2: Verificação de desempenho do equipamento na geração de dados de fluência. In: Anais do II Encontro de Tecnologia e Utilização dos Aços Nacionais; 1987; Rio de Janeiro. Rio de Janeiro; 1987. p. 935-948.

11. Bueno LO. Creep Behaviour of 2.25Cr-1Mo steel - An equivalence between hot tensile and creep testing data. In: Proceedings of ECCC Creep Conference; 2005, Londres. DEStech Publ.; 2005. p. 969-980.

12. Reis Sobrinho JF. Correlação entre os Comportamentos de Tração a Quente e Fluência do Aço 2,25Cr-1Mo na Faixa de Temperatura de $500{ }^{\circ} \mathrm{C}$ a $700{ }^{\circ} \mathrm{C}$. [Tese]. São Carlos: Universidade Federal de São Carlos, 2004.

13. Dias CRF and Bueno LO. Correlação Tração a Quente e Fluência para o Cobre Comercial Puro. Parte 1: Relações entre Tensão, Taxa de Deformação, Tempo de Ruptura e Temperatura. In: Anais do $65^{\circ}$ Congresso Anual da ABM; 2010; Rio de Janeiro. Rio de Janeiro; 2010. p. 1246-1255. Available from: <http://www.abmbrasil.com.br>.

14. Bueno LO. Dados de Tração a Quente e Fluência no Alumínio Comercial Puro: h entre Tensão, Taxa de Deformação, Tempo de ruptura e Temperatura. In: Anais do Seminário de Metais Não Ferrosos ABM; 2011; São Paulo. ABM; 2011. Available from: <http://www.abmbrasil.com.br>.

15. Bueno LO. Tração a Quente e Fluência no Latão Comercial. Parte 1: Relações entre Tensão, Taxa de Deformação, Tempo de Ruptura e Temperatura. In: Anais do Seminário de Metais
Não Ferrosos ABM; 2011; São Paulo. ABM; 2011. Available from: <http://www.abmbrasil.com.br>.

16. Bueno LO and Reis Sobrinho JF. Correlation Between Creep and Hot Tensile Behavior for $2.25 \mathrm{Cr}-1 \mathrm{Mo}$ Steel from $500^{\circ} \mathrm{C}$ to $700{ }^{\circ} \mathrm{C}$. Part 1: An Assessment According to usual Relations Involving Stress, Temperature, Strain Rate and Rupture Time. Revista Materia. 2012; 17(3):1098-1108. http://dx.doi. org/10.1590/S1517-70762012000300007

17. Reis Sobrinho JF and Bueno LO. Correlation Between Creep and Hot Tensile Behaviour for 2.25Cr-1Mo Steel from $500{ }^{\circ} \mathrm{C}$ to $700{ }^{\circ} \mathrm{C}$. Part 2: An Assessment According to usual Relations Involving Stress, Temperature, Strain Rate and Rupture Time. Revista Matéria. 2005; 10(3):463-471. http://dx.doi. org/10.1590/S1517-70762012000300007

18. Viswanathan R. Damage Mechanisms and Life Assessment of High-Temperature Components. Palo Alto: ASM International; 1993.

19. American Society for Testing and Materials - ASTM. Supplemental Report of the Elevated-Temperature Properties or Chromium-Molybdenum Steels. Philadelphia: ASTM; 1966. Data Series Publication DS 6S1.

20. National Institute for Materials Science - NIMS. Data Sheets on the Elevated-temperature Properties of 2.25Cr-1Mo steel for Boiler and Heat Exchanger Seamless Tubes (STBA 24). Creep Data Sheet No.3B. Tsukuba: NIMS; 1986.

21. National Institute for Materials Science - NIMS. Long-Term Creep Rupture Data obtained after Publishing the Final Edition of the Creep Data Sheet, Creep Data Sheet, n. 50. Tsukuba: NIMS; 2004. 